\title{
Challenges and Opportunities for Public Participation in Urban and Regional Planning during the COVID-19 Pandemic-Lessons Learned for the Future
}

\author{
Marijana Pantić $^{1, *(\mathbb{D})}$, Juaneé Cilliers ${ }^{2}$, Guido Cimadomo ${ }^{3} \mathbb{D}$, Fernando Montaño ${ }^{4}$, Olusola Olufemi ${ }^{5} \mathbb{D}$, \\ Sally Torres Mallma ${ }^{6}$ (D) and Johan van den Berg ${ }^{7}$
}

Citation: Pantić, M.; Cilliers, J.; Cimadomo, G.; Montaño, F.; Olufemi, O.; Torres Mallma, S.; van den Berg, J. Challenges and Opportunities for Public Participation in Urban and Regional Planning during the COVID-19 Pandemic-Lessons Learned for the Future. Land 2021, 10, 1379. https://doi.org/10.3390/ land10121379

Academic Editor: Alexandru-Ionuţ Petrişor

Received: 5 November 2021

Accepted: 8 December 2021

Published: 13 December 2021

Publisher's Note: MDPI stays neutral with regard to jurisdictional claims in published maps and institutional affiliations.

Copyright: (c) 2021 by the authors. Licensee MDPI, Basel, Switzerland. This article is an open access article distributed under the terms and conditions of the Creative Commons Attribution (CC BY) license (https:/ / creativecommons.org/licenses/by/ $4.0 /)$.
Institute of Architecture and Urban \& Spatial Planning of Serbia, 11000 Belgrade, Serbia

2 Faculty of Design, Architecture and Building, University of Technology Sydney, Sydney 2007, Australia; jua.cilliers@uts.edu.au

3 Department of Art and Architecture, Escuela Técnica Superior de Arquitectura, Universidad de Málaga, 29016 Málaga, Spain; cimadomo@uma.es

4 Digital City Science, HafenCity Universität, 20457 Hamburg, Germany; fermontz8@gmail.com

5 Independent Researcher, Tanner Court, Oakville, ON 1497, Canada; solaoluf@yahoo.com

6 Faculty of Architecture and Urbanism, Universidad Ricardo Palma, Lima 15039, Peru; sally.torres@urp.edu.pe

Urbanissimo bv, 3650 Dilsen-Stokkem, Belgium; info@urbanissimo.be

* Correspondence: marijana.d.pantic@gmail.com

\begin{abstract}
The COVID-19 pandemic has spurred significant changes in the fields of economic development, social issues, everyday life, etc. Activities that used to depend on face-to-face communication were firstly suspended and then shifted to new forms of communication. This includes the public participation process in urban and spatial planning. Therefore, this study explores the new domain developed in urban and spatial planning with regard to public participation and surmises future realms in the post-pandemic era. On the occasion of the virtual collaboration platform Cyber Agora organized by the ISOCARP (International Society of City and Regional Planners), chosen participants got together virtually to share, discuss, and compare their practical knowledge in public participation before and during COVID-19. In addition, they addressed the potential benefits of shifting from traditional to virtual participation and potential benefits in the post-COVID-19 era. Considering the collected data and understanding them in the light of the available literature, this study concludes that the application of a combined approach (using both traditional and virtual modes of participation) is recommended because it would enable a larger number and higher diversity of participants. The study also elaborates particular modes of virtual participation with the pros and cons of their use in a particular context.
\end{abstract}

Keywords: collaborative decision making; urbanism; spatial planning; online platforms; lockdown

\section{Introduction}

Public participation in urban and regional planning increases the chances that decisions correspond to the diverse interests and needs of different stakeholders and citizen groups [1-5]. It also brings implementation closer to cost-effective investments and builds the trust and satisfaction of citizens toward the government [5]. However, at the beginning of its development, participatory planning was reserved solely for the elite [6], which changed in some countries in the second half of the 20th century [3]. The relevance of citizen participation has increased and become necessary in planning processes [7].

Since the COVID-19 pandemic prompted a lockdown in almost all countries in the world [8], governments and planners were forced to improvise or develop a new functionality for public spaces [9] and methods of participation [10-13]. Many techniques characteristic of the traditional approach to participation, which required face-to-face interaction, have become unviable with the COVID-19 outbreak [14]. Therefore, the use of 
technologies and virtual space has become a focal point in the development of new participation approaches [12] and conducting studies dealing with the new roles of information and communication technologies (e.g., [15]).

Although the use of the internet was seen as anarchic at the beginning of its existence [16], it has significantly evolved, and its use exploded [17]. Together with new technologies, the internet transformed the possibilities of collaboration [18], networking [19], and participation itself [20,21]. Thus, it has developed into a "democratizing force" that facilitates in particular the involvement of young people and individuals with disabilities in participative processes [21-23]. About a decade ago, the use of the internet and technologies was seen as an opportunity to upgrade participation, but it was also open to criticism that the same people would always be interested in participation regardless of the methods used [24]. Some cities have developed efficient virtual systems of data collection, and $[25,26]$ expressed concern that citizens are being reduced to the role of a sensor, with no meaningful exchange with planners and government. The point might be, as [27] notes, that the internet still needs to be improved in order to evolve from a "public space" into a "public sphere".

Authors such as $[10,28,29]$ examined the most plausible scenarios in the post-COVID19 era regarding participatory planning. All of them noted that a shift of paradigms took place during the COVID-19 pandemic, inevitably leading toward new shifts in the postpandemic era. The authors of [23,30-32] proposed that the introduction of technology in the participatory process during the COVID-19 pandemic will turn into a "new normal" in the period to come.

The purpose of participation should not only be voting for the offered solution, but also debate with a vivid communication exchange through which an idea will be developed [33,34], especially in the early stages of any planning process. This is one of the reasons for the skepticism related to certain forms of virtual participation in urban and regional planning, such as online questionnaires or data collection via mobile phone applications. Regardless of the compensatory aspects of virtual participation during the COVID-19 pandemic, [34] noticed that the current legal context needs to be changed in order to equalize participants' decisional power to its extent in an institutionalized traditional approach. According to [34,35], there is no solid evaluation of the e-planning and virtual approach; therefore, its effectiveness in participation is not clear. The COVID-19 pandemic has created a specific context and rapidly prompted both the ad hoc and planned development of new virtual approaches. Their challenges and opportunities have yet to be explored and determined. Therefore, this paper evaluates these aspects of public participation in urban and regional planning, additionally discussing lessons learned for the post-COVID-19 era.

This paper first presents short histories and the contexts in which public participation and virtual public participation have developed in the case study countries. Subsequently, it presents results from the conducted survey. Lastly, the results are discussed and conclusions are noted in light of other academic literature.

\subsection{The Practice of Public Participation}

The idea of public participation in urban planning was born with Jean Jack Rousseau in the 18th century. However, its application and institutionalization took another two centuries [36]. The concept was first adopted nationally; however, with the Rio Declaration on Environment and Development in 1992 [37], which promoted participation at the global level, it has become a constitutional part of other international documents such as the Leipzig Charter on Sustainable European Cities (Leipzig Charter 2007) [38], Treaty of Lisbon [39], and the New Leipzig Charter [40].

The time frame in which public participation was formalized in the planning of analyzed countries spans a long period and features different evolution threads. Starting in the 1920s, Canada was the first to introduce the institution of participation in planning, which has increased significantly since then [41]. Unlike other socialist countries at that 
time, the involvement of the public in planning in Serbia (formerly part of Yugoslavia) was established in 1949 by the "Basic Decree on the Master Urban Plan" (Osnovna uredba o generalnom urbanističkom planu) [3]. Unlike the other countries analyzed in this paper, the development of public participation fluctuated significantly in accordance with sociopolitical changes; the highest level of participation was recorded in the 1970s, then subsided during the 1990s, was quite restricted in 2003, and improved slightly in 2014 compared to 2003, but not compared to the 1970s [3]. The first federal regulations for the participation of citizens in urban planning in Germany date from 1960 [42], and they were later modified and improved (e.g., German Building Law of 1976 [43], European Construction Law Adaptation Act [44,45]). In Belgium, public participation arose in the 1960s from resistance to decisions and was unregulated, before being formed into a mandatory procedure; since the 21st century, it involves mandatory dialogue and testing. In Spain, public consultation, as a first step in the development of urban and territorial planning, was implemented only with the promulgation of the Planning Regulation for the development and application of the Law on Land Regime and Urban Planning of 1978, art. 116.1 [46], which is, among others, a result of the first democratic elections in 1977 after a long dictatorship period. It was nevertheless an indirect kind of participation, fostered only by those public institutions that considered it necessary in the preliminary phases of planning to collect all kinds of stakeholders' opinions. These ideas were implemented in very few cases [47]. Public consultation in different stages of urban development was regulated only with the promulgation of the Land Regime and Valorization Law [48,49]. In Peru, mandatory participation was introduced by the Rights of Citizen Participation and Control Law-Law No. 26,300 in 1994 [50] to strengthen the process of the country's democratic acculturation. In addition, the UNDP and the National Elections Jury published a guide in 2008 to establish mechanisms for citizen participation that do not generate abuse or chaos [51]. Lastly, public participation in South Africa was pushed forward by the "Report on the Assessment of Public Participation Practices in the Public Service" in 2008 [52]. In the report, the Public Service Commission categorically urges government departments to institutionalize the practice of public participation by, inter alia, developing their policies, guidelines, and structures such as dedicated public participation units to drive public participation. Thus, the introduction of public participation into formal procedures in the analyzed countries lasted for almost an entire century, mostly expanding the rights and modes of participation, but also with examples of hindrance and degradation due to political changes (Table 1).

Table 1. Public participation in urban and regional planning.

\begin{tabular}{|c|c|c|c|c|}
\hline \multirow[b]{2}{*}{ Country } & \multirow{2}{*}{$\begin{array}{l}\text { Formalization of } \\
\text { the Participation }\end{array}$} & \multicolumn{3}{|c|}{ Participation Models } \\
\hline & & $\begin{array}{l}\text { Consulting before a } \\
\text { Plan Is Drafted }\end{array}$ & $\begin{array}{l}\text { Commenting on } \\
\text { the First Draft }\end{array}$ & $\begin{array}{c}\text { Commenting on } \\
\text { the Final Draft }\end{array}$ \\
\hline Belgium & $1960 \mathrm{~s}$ & Obligatory & Obligatory & Obligatory \\
\hline Canada & $1920 s$ & Obligatory & Obligatory & Obligatory \\
\hline Germany & $1960 \mathrm{~s}$ & $\begin{array}{l}\text { Non-binding but } \\
\text { commonly practiced }\end{array}$ & Obligatory & Obligatory \\
\hline Peru & $2010 s$ & Obligatory & Obligatory & Obligatory \\
\hline Serbia & $1940 \mathrm{~s}$ & $\begin{array}{c}\text { Non-binding but } \\
\text { occasionally practiced }\end{array}$ & Obligatory & Obligatory \\
\hline South Africa & $2000 s$ & $\begin{array}{c}\text { Non-binding but } \\
\text { occasionally practiced }\end{array}$ & Obligatory & Obligatory \\
\hline Spain & $2000 s$ & $\begin{array}{c}\text { Non-binding but } \\
\text { occasionally practiced }\end{array}$ & Obligatory & Obligatory \\
\hline
\end{tabular}

Except in countries where formalized public participation was established before the 2000 s, a combination of formal elements with nonbinding approaches of participation is common along with obligatory terms of public participation. In Belgium, progressive cities and companies go beyond formal regulations and open explicit dialogue with residents and the population with scenarios. Under the repealed Canada's Environmental Assessment Act (CEAA), a public participation guide for environmental assessments required 
obligatory and meaningful participation, but there was also voluntary and nonbinding participation in other aspects that required public input in other planning processes. The Guide to Canada's Impact Assessment Act, 2020 (formerly the CEAA) introduced substantive changes that broaden the scope of all federal assessments, and the new Impact Assessment Act (IAA), which went into effect in August 2019, represents a fundamental shift in federal environmental assessment in Canada [53]. The IAA [54] has a clear Public Participation Plan which helps to identify and address the potential impact of a designated project. Due to Germany's federal system, there are guidelines in the different German states (Länder) that derive their basis from federal law and stipulate specific regulations on citizen participation in addition to regulations at the federal level. Second-level regulations have been applied in all states except one during the 1990s [45]. As in Germany, urban and territorial regulations in Spain are delegated to regions (comunidades). "Indirect democracy" intended as the right of neighbors to be informed and to participate in public affairs has been regulated since 1985 by the Law Regulating the Bases of Local Governments [55] and was extended to the specific planning framework in the Land Regime and Valorization Law [48]. "Direct democracy" or full participation in defining the transformation of urban models is nonbinding and implemented by planners and several municipalities that understand the benefits of citizens' involvement. True participation is only possible when municipalities or planners foster strategies that include "novel" approaches.

\subsection{The Practice of Virtual Public Participation}

In contrast to traditional forms of participation, virtual public participation is not legally binding in all the analyzed countries. In Belgium, Germany, Peru, and Serbia, the practice of virtual public participation is partially defined by regulations, whereas nonbinding forms were developed along the way. In other countries, the COVID-19 pandemic was the trigger for the use of virtual participation (Table 2).

Table 2. Virtual public participation in urban and regional planning.

\begin{tabular}{|c|c|c|}
\hline Country & When Consideration of the Practice Began & Formalization of Virtual Participation \\
\hline Belgium & $\begin{array}{l}2020 \\
\text { due to the COVID-19 pandemic }\end{array}$ & $\begin{array}{l}\text { Nonbinding but intensified due to the } \\
\text { COVID-19 pandemic }\end{array}$ \\
\hline Canada & The 2010 s & $\begin{array}{l}\text { Obligatory, changes made due to the } \\
\text { COVID-19 pandemic }\end{array}$ \\
\hline Germany & The late 1990s & Obligatory \\
\hline Peru & $\begin{array}{l}2020 \\
\text { due to the COVID-19 pandemic }\end{array}$ & $\begin{array}{l}\text { Nonbinding but intensified due to the } \\
\text { COVID-19 pandemic }\end{array}$ \\
\hline Serbia & The late 2000s & $\begin{array}{c}\text { Obligatory, but only regarding public } \\
\text { information; new nonbinding forms developed } \\
\text { due to the COVID-19 pandemic }\end{array}$ \\
\hline $\begin{array}{l}\text { South } \\
\text { Africa }\end{array}$ & The 2010s & $\begin{array}{l}\text { Nonbinding but intensified due to the } \\
\text { COVID-19 pandemic }\end{array}$ \\
\hline Spain & The 2000s & $\begin{array}{l}\text { Obligatory, but only regarding } \\
\text { public information }\end{array}$ \\
\hline
\end{tabular}

Independent of COVID-19, Germany was the first to consider virtual participation in planning in the late 1990s and early 2000s. The first large-scale study of E-Citizen Participation in German Cities was launched in 2004: “Digital Citizens' Participation in Germany's Large Cities 2004" ("Elektronische Bürgerbeteiligung in deutschen Großstädten 2004") [56]. With the most recent amendment to the Building Code (BauGB), the additional use of the internet has become mandatory for public participation in building land-use planning since May 2017 (Section 4a (4) BauGB). The documents must be displayed and accessed by the public, for example, via the municipality's internet portal [57].

The Revised Text of the Land and Urban Rehabilitation Law 7/2015 [58] in Spain made virtual participation obligatory, but only in terms of publishing current urban plans, public consultation calls, and information on the internet. Due to the delegation of administrative management, some regions applied similar rules earlier, as well as fostered the presentation of queries in a digital format (Andalucia since 2013 with the Transparency, Access to 
Public Information and Good Governance Law 9/2013 [59]). By the end of the 2000s, the municipality of Rivas Vaciamadrid (Spain) fostered real virtual participatory processes spurred by the ambition to reach all community members [60].

In Serbia, the Law on Planning and Construction adopted in 2009 [61] required the public display of plans on the internet, thus establishing the first obligatory aspect of virtual participation, which has not developed further since then. However, nonbinding forms started to emerge increasingly with the COVID-19 pandemic. COVID-19 realities also boosted the need for virtual participation in South Africa, although virtual public participation is not a common feature due to technology constraints and limited infrastructure. Similarly, the pandemic hastened alternative ways of participation (meaning virtual participation) in Peru and Belgium.

Pandemic-inspired actions led to official regulation changes in Canada. Canada Bill 189 [62] was an Act to amend various Acts (including the Planning Act) to address COVID-19. Moreover, Ontario Regulation 149/20 [63] stipulates special rules related to the declared emergency. The "Canada Digital Charter in Action" initiative was created earlier. However, specifically since 2020, virtual public participation and engagement have become evident due to pandemic measures such as lockdown and social distancing.

In Peru, the Public Participation and Digital Government Law [64] is mandatory, but work with virtual mechanisms in urban planning began as a result of the pandemic. There is no specific related law, and it is not mentioned in the new Sustainable Urban Development Law of 2021 [65]. There was only one Manual of Metropolitan Development Plans in 2020, where it is recommended to adopt virtual measures for public participation [66]. This is because the development of two metropolitan plans for Lima and El Callao provinces began at the end of 2019 and the beginning of 2020, respectively.

The COVID-19 pandemic is the reason why online meetings have become one of the inevitable tools for public participation in all the analyzed countries. In South Africa, it even became legally binding. Another means of virtual public participation inspired by the pandemic is online voting, which was introduced as legally binding in South Africa and as legally nonbinding in Canada, Germany, Serbia, and Spain. Other forms of virtual public participation were introduced in only a few countries (Table 3). In Ontario, the City of Toronto approved virtual public hearings and participation due to COVID-19 via telephone, tablets, computers, and smartphones.

Table 3. Forms of virtual public participation in urban and regional planning.

\begin{tabular}{|c|c|c|c|c|c|c|c|c|}
\hline \multicolumn{2}{|c|}{ Forms of Virtual Participation } & \multirow{2}{*}{$\frac{\text { Belgium }}{\text { / }}$} & \multirow{2}{*}{$\frac{\text { Canada }}{/}$} & \multirow{2}{*}{$\frac{\text { Germany }}{\text { / }}$} & \multirow{2}{*}{$\frac{\text { Peru }}{/}$} & \multirow{2}{*}{$\frac{\text { Serbia }}{/}$} & \multirow{2}{*}{$\begin{array}{c}\text { South Africa } \\
/ /\end{array}$} & \multirow{2}{*}{$\frac{\text { Spain }}{/}$} \\
\hline Documents available & Legally nonbinding & & & & & & & \\
\hline for public inspection on & Legally binding & Yes & Yes & Yes & Yes & Yes & Yes & Yes \\
\hline a website & COVID-19 inspired & / & / & l & / & / & Yes & / \\
\hline \multirow{3}{*}{ Online voting } & Legally nonbinding & / & Yes & Yes & Yes & Yes & / & Yes \\
\hline & Legally binding & / & / & / & / & / & Yes & / \\
\hline & COVID-19 inspired & / & Yes & Yes & Yes & Yes & Yes & Yes \\
\hline \multirow{3}{*}{ Online meetings } & Legally nonbinding & Yes & Yes & Yes & Yes & Yes & / & Yes \\
\hline & Legally binding & / & / & / & / & / & Yes & / \\
\hline & COVID-19 inspired & No & Yes & Yes & Yes & Yes & Yes & Yes \\
\hline \multirow{3}{*}{$\begin{array}{l}\text { Mobile phone } \\
\text { applications }\end{array}$} & Legally nonbinding & Yes & / & Yes & / & / & / & / \\
\hline & Legally binding & / & / & / & / & / & / & / \\
\hline & COVID-19 inspired & Yes & / & / & / & / & / & / \\
\hline \multirow{3}{*}{$\begin{array}{l}\text { Submission of remarks } \\
\text { and suggestions by } \\
\text { e-mail/digital registry }\end{array}$} & Legally nonbinding & / & / & / & / & Yes & / & / \\
\hline & Legally binding & / & / & / & / & / & / & Yes \\
\hline & COVID-19 inspired & / & / & / & Yes & Yes & / & / \\
\hline \multirow{3}{*}{$\begin{array}{l}\text { Simplified procedure to } \\
\text { consult planners by } \\
\text { phone/mail }\end{array}$} & Legally nonbinding & / & / & / & / & / & / & Yes \\
\hline & Legally binding & Yes & / & / & / & / & / & / \\
\hline & COVID-19 inspired & / & / & / & Yes & / & / & Yes \\
\hline
\end{tabular}

Regardless of the transition to virtual forms of participation, stakeholders have mainly remained the same. Virtual meetings, information on web pages, and online voting were 
accessible to all stakeholders-from citizens to nongovernmental organizations, the civil sector, public institutions, etc. In some cases, the range of stakeholders depends on the type of project (plan), the governmental body responsible for the plan, and other factors. For example, in Germany, there is no exact participation procedure or defined tools, but they could vary depending on the state/local government. In the case of Serbia, alternative (legally nonbinding) documents such as Green City Action Plan (GCAP) were financed by the EBRD and the Japanese government; therefore, the documents went through a different procedure than the Spatial Plan of the Republic of Serbia that was conducted by the state government (both were created during the pandemic). The action plan procedure involved a wider range of virtual participation tools (e.g., online voting, online meetings, and e-mail communication), whereas, for the Spatial Plan, only remarks and suggestions could be sent via e-mail. However, the Spatial Plan involved all possible stakeholders willing to participate, whereas GCAP meetings were mainly accessible to invited City Government representatives.

One of the successful case finalizations of an urban project appears to be the Europaplatz in Tübingen (Germany) (open public space), whose renovation was discussed for 25 years before the COVID-19 pandemic. The last public planning workshop was canceled due to pandemic restrictions tightening in autumn 2020. Instead, a digital format was developed. The planning was explained by various experts in videos. All the information was processed textually and graphically on the website and presented by the daily newspapers. Participation was intensively advertised via various social networks and mailing lists. Valuable suggestions were received such that the planning was modified in parts. The positive vote with $70 \%$ approval and only $10 \%$ clear rejection showed that the planning is based on broad urban society consensus. A comparatively large number of younger people and families were reached. Overall, the media and public considered this to be a success, especially regarding the fact that it was one of the first digital formats for citizen participation in Tübingen and, thus, still in the trial stage [67].

\section{Materials and Methods}

The onset of the COVID-19 pandemic hindered traditional and prompted new forms of public participation in urban and regional planning. Many activities, including planning, were relegated to a position of secondary importance compared to the health (and economic) emergency. This forced shift resulted in a range of ad hoc solutions, simultaneously showing the drawbacks of previously never-tested tools and new opportunities to join the participatory process. The virtual experiences produced under the pandemic will be even more relevant in the future (of planning) than their chance to serve as participation processes during the lockdown. The objective of this research was to investigate the problems of and opportunities for virtual public participation tools and evaluate them with a view to their integration into the official public participation system in urban and regional planning.

This research is, therefore, based on the following hypotheses:

Hypothesis 1 (H1). The ad hoc development and application of virtual participatory tools, which could not be previously tested, highlight problems and obstacles in the public participation process.

Hypothesis 2 (H2). Regardless of their ad hoc development and application, virtual participatory tools show certain advantages that make them worthy of becoming standardized tools in public participation that can even be implemented beyond the present COVID-19 times.

Concerning research design, this research is based on case-controlled studies evaluated by the expert assessment method. Seven countries were analyzed as the case-controlled studies in order to identify the possible predictors of positive outcomes of using virtual participation tools in public participation in urban and regional planning. Case-controlled studies are also referred to as observational studies where, in this particular research, seven experts in urban and/or regional planning (authors of the paper) assessed the problems 
of and opportunities for virtual participation and the prospects of its application in the post-COVID era.

The experts and, hence, the cases were selected by the convenience method with reasoning. Specifically, due to the new pandemic circumstances, the ISOCARP (International Society of City and Regional Planners) organized a virtual collaboration platform (Cyber Agora) for its members. At the point of the COVID-19 outbreak, the gathering of urban and regional planers from all over the globe was considered the best opportunity to recruit professionals in this field, all affiliated with the ISOCARP and being interested and experienced in dealing with participation before and during the COVID-19. On the occasion of the second meeting devoted to "Virtual Public Planning Participation: Hype or New Normal?", the participants were invited to collaborate on the preparation of this study. The authors of this paper are those who accepted and went through the preparation processes. In addition to the convenience of the selection, the choice of case studies also corresponded to the basic reliability criteria: (1) encompassing different sociopolitical backgrounds, (2) involving cases with different lengths of experience in public participation, and (3) addressing experts from both academia and practice.

As a result, the subjects of this research are Belgium, Canada, Germany, Peru, Serbia, South Africa, and Spain. The study is designed as exploratory research in which data collected for the analysis include expert observations and assessments by the authors of the paper, as well as assessments reported in the academic literature and media on understanding the implications for public participation in urban and regional planning during the COVID-19 pandemic. Primary data (the authors' observations and assessments) were collected by survey, technically supported by the Google Form platform. Survey-based research is conducted without predetermined notions of the expected responses [68]. Such surveys are common in social and psychological research and are often used to describe and explore human behavior [69]. The questionnaire in this study consisted of 42 questions divided into four major topics: (1) main characteristics of the planning systems, (2) formal/informal occurrence of virtual public participation, (3) public participation challenges occurring during the COVID-19 pandemic, and (4) public participation opportunities developed during the COVID-19 pandemic. More than half of the questions were open-ended, whereas the remaining questions were multiple-choice with the possibility of entering original answers ("Other:... "). This way, a balance was enabled between new knowledge and the comparability of the answers.

A qualitative evaluation was made of the collected data. Despite the possibility of quantifying some of the answers collected by the survey, the fact that the research involves only seven countries influenced the decision to evaluate the results qualitatively. The responses were interpreted narratively, with the frequent use of phrases characteristic for qualitative research (e.g., "predominantly", "mostly", "hardly", "on average", "majority"). In addition, the categorization method was used to identify the main groups of challenges to and opportunities for virtual participation.

\section{Results}

\subsection{Challenges to Virtual Public Participation}

The challenges to virtual participation in urban and regional planning are not necessarily related to the shift from traditional to virtual platforms. In general terms, COVID-19 caused timeline, deadline, and process delays; however, despite a certain level of adaptation to the new context, virtual participation also suffered from the insufficiencies inherited from traditional forms of participation. This included the challenge of reaching all relevant stakeholders (particularly vulnerable groups), as well as participants' knowledge and understanding of planning procedures and aims.

However, experiences from the analysed countries indicate that virtual public participation during the COVID-19 pandemic has met specific challenges. These challenges can be categorised as follows: (1) accessibility, (2) reliability, and (3) trustworthiness. 
This section may be divided by subheadings. It should provide a concise and precise description of the experimental results, their interpretation, as well as the experimental conclusions that can be drawn.

\subsubsection{Accessibility}

The accessibility issue refers to inequalities in terms of participation from the moment when the internet and technical equipment (computers and mobile phones) became an essential prerequisite for participation in planning. Even though it was not intentional, experiences from the analyzed countries show that accessibility to virtual participation was hindered by (a) an urban-rural divide, (b) a wealthy-poor divide, (c) a young-elderly divide, and (d) a gender divide. According to the survey, Canada, South Africa, and Peru were challenged the most, while Belgium successfully diminished the problem.

Since the pandemic, it should be noted that rural municipalities have had difficulty participating because of poor access to the internet. To address this inequity, postcards of notification and hard copies of documents were sent to be picked up at certain locations in Canada. The significant difference in infrastructure levels between urban and rural areas in Serbia includes the road infrastructure, water supply, sewage system, and accessibility to the Internet [70]. As rural areas are usually populated by an older population, the accessibility problem increases. In Spain, internet access of the elderly population (65-74 years old) is $69.7 \%$, which is significantly smaller compared to the average of $93.2 \%$ (16-74 years old) [71]. As in many world cities, the COVID-19 pandemic also highlighted the digital divide and inequalities within Canadian communities. Wi-Fi hotspots and public spaces, public libraries, and restaurants providing Wi-Fi access became unavailable during COVID-19 lockdown periods, whereby a large number of residents were left without internet access.

In Canada, online inequality and poor access to the internet were problematic not only for seniors but also for people with disabilities and BIPOC (Black Indigenous People of Color) in low-income neighborhoods. Limited access to digital platforms is, thus, a common feature. In most cases, it was the vulnerable and disadvantaged communities that were most affected by internet access during the lockdown. In rural communities, there are often fewer internet services and lower internet service speeds compared to urban centers [72]. In Spain, it was determined that 91.4\% of Spanish households have access to the internet, but the COVID-19 pandemic highlighted that low-income families in this country have access mostly through mobile devices. Although this might seem adequate, it was found that this situation leads to a wider divide.

The inclusiveness of marginalized groups in some societies remains a global challenge. There are cultures where not all community members can speak up during public meetings or have access to mobile phones or the internet. Therefore, their attempts to reach out to these groups digitally are more challenging.

Inequality in terms of accessibility is further magnified by uneven digital literacy, where elderly and rural populations in particular show lower levels of computer literacy. In this sense, digital infrastructure, access, and literacy became very relevant for virtual public participation during the COVID-19 lockdown. In Serbia, for example, more than half of the population $(51.0 \%)$ over 15 years of age is computer-illiterate, with substantial regional differences [73]. The Government of Ontario (Canada), therefore, allocated 150 million CAD to expand broadband internet across the province, as part of a previous 315 million CAD plan developed to improve digital connectivity in rural communities, emphasizing the high costs associated with technology advances, but also the importance of leadership and political will in addressing inequality in technology accessibility.

\subsubsection{Reliability}

Due to its ad hoc development and considerable improvisation, virtual participation still has not had the opportunity to solve technical and methodological issues. Therefore, a range of challenges were recognized, starting with (a) the gap between traditional and 
virtual participation, (b) the lack of virtual participation methodologies, (c) poorly targeted participants, (d) the rigid discussion structure, (e) anonymity, (f) the lack of informal discussion, (g) "self-service", and (h) the lack of reliance on body language. Some countries, such as Belgium, found a new efficient way to involve citizens, which works well despite the initial skepticism. In contrast, South Africa and Peru reported the greatest difficulties.

There is limited knowledge of virtual participation methodologies. Virtual engagement can be negatively and automatically characterized as being inequitable. Judging by the experience in South Africa, virtual communication is emphasized more than virtual participation. Large Zoom meetings are possible but expensive; therefore, not all interested parties can participate at once. This diminishes the value and the purpose of the discussion. This is often viewed as a lesser investment of resources and is, thus, equated with a lesser effort to engage diverse and representative participants within a community. In Serbia, citizens were deprived of the public presentation of the Spatial Plan of the Republic of Serbia. This and similar deficiencies in supportive documentation and data are a barrier to proper presentation of the plans and, hence, meaningful participation.

Due to the sudden shift from traditional and well-known methods of participation materials and participation itself, some stakeholder groups and citizens were left out. The narrower scope of participants was risky in terms of the involvement of all target groups, which led to the provision of false information.

Online voting (survey) on a specific aspect of a plan provides easy access, but it is also usually anonymous. Thus, it is a safe place to express opinions, but the accountability of the contributors should be carefully considered, since the outcomes of "self-service" further guide public spending and affect others. The City of Belgrade (Serbia) also tested the possibilities of such virtual participation through the Green City Action Plan for the City of Belgrade, which was envisioned as a participatory procedure to define a vision, mission, and main objectives. The primary idea was to gather various parties in a workshop, which was dismissed after the COVID-19 crisis accelerated. To enable the timely completion of the project, the consultant and the City decided to provide public online voting where citizens could suggest various proposals. The submitted proposals showed a lack of understanding of the term "vision". This example pointed out the great relevance of well-trained moderators in leading the participation process, since they are excluded by default in forms of virtual participation such as online voting (survey).

Similar findings were recorded in Spain with a preliminary participatory process conducted in Santander in July 2020 during the lockdown period. The process constituted in-person and online activities, but the latter lacked explanations. Moreover, limited space was provided for participants to include personal opinions and suggestions, thus limiting participation and failing the objective of being citizen-driven.

Furthermore, the apathetic nature of virtual participation means that it is not possible (in most cases) to read body language, further limiting meaningful conversation and the reliability of the participation results. Virtual discussions tend to have more rigidly structured questions compared to in-person discussions; thus, they do not lead to discussions outside their realm that may be important depending on the sociocultural circumstances. In digital media, there may be a degree of abstraction and social isolation that can reduce the joy associated with a group effort, which discourages potential participants from taking part.

In Lima, different results were achieved when the participatory processes of the Metropolitan Development Plan (which started in late 2019) were taken online. There were very limited discussions, and this created further uncertainty for the stakeholders. In Serbia, especially in rural areas, it was also found that stakeholders were bewildered by the unexpected transition to virtual means of discussion. In Munich (Germany), on the other hand, strict planning regulations and formal processes lacked the freedom of participatory and cocreation formats. As mentioned in the ongoing Smart Together program "not all local problems can be solved with the smart city project, which can lead to frustrations of residents" [74]. Other cities, however, do embrace the benefits of participatory planning. For example, in Antwerp (Belgium), the enormous resistance to finishing the city ring grew 
into a collaboration with Ringland authorities, which resulted in the ring being covered in strategic places, such that the city is connected to its spacious surroundings by parks.

\subsubsection{Trustworthiness}

Remote communication and "self-service" participation only accentuate the issue of trust between governments and experts, on the one hand, and participants, on the other. In the survey conducted for this analysis, the experts identified the following aspects that harm trustworthiness in virtual public participation: (a) depersonalized participation, (b) give-up rate, (c) mistrust in the corrupted system, (d) fear of misuse of personal data, (e) interference of hackers, and (f) appearance of fewer efforts. The most concern regarding these aspects was shown in South Africa, whereas it was very little in Serbia and Spain, and completely insignificantly in Belgium.

Even when public administration offers online services, some citizens might still prefer to use traditional (in-person) ways to communicate with the local administration, arguing that it might provide an opportunity for more interaction and clarification regarding intentions and attitudes. There is often the lack of a "human touch" when face-to-face engagements are replaced by virtual encounters. Members of some communities feel more confident sharing details with people of the same gender or ethnicity. Virtual participation does not seem as inviting as face-to-face collaborations, and a preference for tête-à-tête communication deters some participants from involvement in virtual participation. Video call meetings might make it easier to be present, but they do not necessarily enhance participation, especially since some participants tend to keep their microphone muted and video off, thus depersonalizing their participation to the maximum. A facilitator would tend to skip such participants during the discussion and would, thus, limit the meaningfulness of the participation.

Inclusive virtual participation could face more challenges in cities where there is poor trust in governance. For example, in Lima (Peru), significant omissions are evident in city planning due to corruption, weak coordination mechanisms by the Metropolitan Governance, and the lack of an official term for planning in the Peruvian legislation. Research on the biosphere reserve in Serbia has shown that trustworthiness and overall willingness to participate in planning processes highly depend on the implementation success of previous projects based on a participatory approach. The perception that a complex matter is difficult to do online, along with mistrust in the use of personal data on the internet, plays an important role when attracting people to take part in virtual participation. When it comes to the use of technologies, especially applications, citizens showed skepticism regarding personal data manipulation, while participation hosts encountered problems caused by hackers.

\subsection{Opportunities for Virtual Public Participation}

Virtual participatory planning approaches do, however, provide various opportunities to improve public participation. Some of the opportunities are even universally applicable to all three groups of challenges-accessibility, reliability, and trustworthiness. The case of the town of Hildesheim (Germany) has shown that online participation in times of a pandemic can certainly work and also lead to good and usable results. The number of clicks and participants proved that a high number of people could be reached [75].

Virtual platforms were also found to make it easier to engage with larger audiences. In Lima, for example, given the COVID-19 pandemic, citizens' and architects' participation in virtual conferences, seminars, and forums developed by the College of Architects of Peru greatly increased. This was seemingly due to the elimination of commuting to the venue, as well as growing interest in topics about the city's future.

In 2019, in Rivas Vaciamadrid, a small city in Spain with 88,150 inhabitants, a digital platform for participatory budgeting attracted approximately 200 proposals, followed by 3000 votes. The platform enabled an easy evaluation process, resulting in 14 actions being duly selected for funding, worth 300,000 EUR. In Munich, it became evident that 
a combination of working offline and online can lead to better results, for example, optimizing workshops using the MunichApp in combination with existing events and local bottom-up initiatives. However, the overall impression in Spain is to be cautious, since the opportunities for virtual participation during COVID-19 could lose their relevance in post-COVID times. After all, the lockdown unencumbered many people who had more time to participate in online meetings. This does not necessarily mean that, in the future, virtual activities will not have the same number of participants.

Therefore, Spain is the only example that does not see shifts during the COVID19 pandemic as a sound opportunity to improve accessibility to participation through lower costs in organizing (no expenses for the venue and catering) and participating (no need to travel), as well as a significantly smaller time requirement when participating from a personal computer/mobile phone. Even though the reduced costs and lower time requirement were identified as opportunities in the majority of the analyzed countries, they did not significantly influence the number of participants in Serbia and Spain. However, if a virtual meeting had taken place in the case of Serbia's National Spatial Plan, the results would have been different, because an opportunity would have been provided for citizens outside of the capital city to participate, thus having a much better inclusion of rural and remote areas.

Similarly, it was noticed that young people are more comfortable using new technologies than older people. Therefore, virtual participation balanced out young people with experienced citizens in Canada, Germany, Peru, and South Africa, but not in Belgium, Serbia, and Spain. In the latter three countries, a misconception was noted about the digital knowledge of the elderly who are eager to learn, especially since COVID-19, and who wish to improve their information and gain inspiration. In addition, the youngest generations were not included, since having technological skills without experience does not necessarily mean an improvement in participation. The target group of participants was aged $30-50$ years.

Representatives of all the analyzed cases were nevertheless unified on the matter that some applications (e.g., Zoom) are an opportunity to improve trustworthiness by running polls and presenting the results during meetings. Virtual participation processes assist with the facilitation of meetings, as the platform ensures that all voices are equal, rather than the frequent scenario where the "loudest person is heard". Six out of seven experts estimated that user-friendly interface applications could enhance participatory approaches and quality control, as well as present information effectively and transparently via virtual platforms, thus contributing to accessibility, reliability, and trustworthiness. Virtual platforms could ensure that reachability is extended even further, especially through asynchronous processes and by providing the option to view the recording of events at a convenient time and day. Virtual platforms make it possible to extend inclusiveness and overcome many of the traditional barriers to participatory processes.

The research identified that virtual platforms often lead to promptly obtained results. Voting for scenarios can be done virtually (graphically, with videos telling the story and explaining the scenarios). Virtual participatory platforms enable measurable results from the input of all participants, and these inputs are formally acknowledged through the digital structures. The city of Munich, for example, has created a smart data platform for the project Smarter Together known as the Transparency Dashboard, which gives interested people a clear and comprehensive overview of what kind of data are being collected in the project, how they are processed, and the measures taken to protect data and privacy, among others [74]. These digital advances improve transparency and, as a direct result, enhance trustworthiness. Two experts agreed that virtual platforms provide an opportunity to build trust in their countries, four of them thought that virtual platforms help to overcome language barriers, and three of them thought that COVID-19 is an opportunity to rethink "business as usual". 


\subsection{Legacy for Post-Pandemic Times}

The pandemic has forced many municipalities to move toward digital participatory methods to continue developing their ongoing urban projects. Some of them have had the opportunity to try different digital tools and assess them on the basis of their own experience. There have been some difficulties given the novelty of these methods, but a considerable number of municipalities are satisfied with implementing online methods. They were able to reach more people with good levels of participation. At the same time, they have seen the multiple possibilities offered by online tools and how to combine them with well-known offline participatory methods.

They have become more aware of the importance and need for virtual participation, as experienced in Belgium, Germany, Peru, South Africa, and Serbia. The advantages, such as the easier organization of online discussions, as well as data collection (opinions) via websites, e-mails, and digital registries, have made governments realize that methods developed to deal with the specific conditions of the pandemic are also practical for post-pandemic times. For example, in Germany, public participation, which used to be primarily analog, is now inevitably becoming largely digital. All over Germany, cities such as Hildesheim, Duisburg, Dortmund, Munich, Frankfurt, and Lindau are calling for digital participation formats for the development of planning areas [76]. Numerous cities have developed online participation formats such as online meetings, online voting, and increasing communication on social media.

Governmental actions in Canada went beyond awareness and the idea of new possibilities, since amendments were made to the legislation. For example, Ontario's Bill 197 (Chapter 18 of the Statutes of Ontario) [77] is an Act to amend various statutes in response to COVID-19 and to enact, amend, and repeal various statutes, Bill 189-Chapter 6 [64] is an Act to amend various Acts to address COVID-19, and Ontario Regulation 149/20 Special Rules Relating to Declared Emergency [65] is the provincial legislation that sets the rules for land-use planning in Ontario.

In any case, there is still a long way to go in most other countries when it comes to the implementation of these new tools for urban planning purposes. In South Africa, for example, the issue is limited funds and willingness to invest in such infrastructure, whereas, in Serbia, there is a fear that the government will use the inclusion of online meetings as justification for the exclusion of in-person dialogue between experts and citizens in public inspections. In Spain, a different understanding of the value of public participation in the whole process of planning (empowerment of neighbors) would be the first step toward the later implementation of all kinds of virtual participatory processes. Several experiences, such as in the cities of Rivas Vaciamadrid, Santander, Oviedo, or Albacete, despite the focus on smaller city areas, show the worthiness of the participatory approach.

All experts nevertheless agreed that the most successful aspects of public participation created during the COVID-19 pandemic should remain part of regular planning practice. The main arguments in favor of this were as follows: they do not contravene the application of a traditional approach; online meetings are an opportunity for those who cannot participate due to time constraints to see the recorded video; new virtual participation and public discussion can reach a greater number of citizens along with a different target of stakeholders; digital submissions of remarks and suggestions might be easier for citizens, governments, and consultants; a digital record of entries is easier to sort and integrate into public reports. The development of a hybrid model of public participation is seen as a win-win situation for all.

Out of 13 opportunities recognized in the analysis, experts from Canada, Germany, and South Africa estimated that more than 10 of these would be suitable as part of traditional planning in the future, and experts from the other countries chose between six and 10. There are two opportunities that all experts considered relevant to keep as part of regular practice: (1) recorded online meetings because they enable their content to be seen by groups of interested stakeholders that could not participate in the meeting, and (2) the use of applications that allow the creation of polls during the meetings so that results 
can be shared with participants immediately. The majority of the experts also considered that virtual participation is an excellent opportunity to enlarge the number of participants willing to get involved due to (1) lower costs for the participants (no need to travel), (2) smaller time demands (no traveling to the venue and back), and (3) an easier evaluation process enabled by the use of online platforms.

Less popular, but still chosen by the majority of experts, were opportunities to (1) balance out young people with experienced citizens because they are more comfortable using new technologies, (2) reduce costs for the organizers (no venue, catering, etc.), (3) enhance participatory approaches and quality control with the help of user-friendly interface applications, (4) rethink "business as usual", and (5) be more transparent by effectively presenting information via virtual platforms. Only a few experts considered that virtual platforms help to overcome language barriers and build trust between participants and government/consultants.

\section{Discussion and Conclusions}

This study showed that virtual participation in urban and regional planning faces similar drawbacks to those in traditional planning participation, such as the participants knowledge of planning principles and goals, as well as the involvement of a large number of stakeholders from diverse sectors and spheres. As [78,79] noted, the majority of the population is not interested in active participation in decision making, but they often get involved in order to protect their private interests. They do not realize the benefits or the important contribution of citizen participation [80]. Compared to traditional ways of participation, participants' knowledge must include how to use the technology (computer/mobile phone) and applications installed on electronic devices. Although [81] stated that technological possibilities and skills no longer represent an obstacle, [82] noted that technological literacy is developing gradually, and that part of the population is still not familiar with or comfortable using ICT.

On the one hand, the use of technologies in the participation process opens the possibility of involving a larger number of people and, hence, a broader scope of stakeholders. This issue has also been broadly addressed in other sources. The authors of $[2,11,15,19-21,83]$ considered that virtual participation enables more flexible involvement of stakeholders and saves time and money for both organizers and attendees. If these are the reasons why participants should take part in the processes, technology and accompanying software make it possible. Forms of participation that do not require discussion also help; potential participants can share their opinions at a time that suits them best via e-mail, online questionnaire, survey, online platform, etc. [15]. Virtual participation eliminates the dimension of physical distance [84] and reduces the $\mathrm{CO}_{2}$ footprint due to reduced travel $[83,85]$.

On the other hand, it has been noted by other researchers that using a solely virtual approach eliminates some participation from the public participation process [82], especially in the case of the elderly [7]. Those who are used to traditional participation forms, do not have a computer/mobile phone, or are not sufficiently familiar with the use of technology could choose or be forced to stay out of the participation process. Additionally, part of the population does not have internet access, which implies a digital divide when combined with the lack of technical equipment and knowledge [13,21].

Technical knowledge and internet access are closely related to the local context: individual and group access to the infrastructure and their social status. Thus, the digital divide results from the urban-rural [86], wealthy-poor [12,13], young-elderly [21,87], and gender divides $[12,82,87-89]$, as recognized in this study and by other authors. It was also noted, as confirmed by [11], that the divide based on social status is the foundation for the divide based on skin color. The authors of [90] also registered the problem of disabled persons who might be included in the participation more easily with the introduction of technological means, but only if the interface is adapted to their requirements.

Therefore, overcoming technical obstacles is relevant to improving the possibility of marginalized groups' participation and overcoming difficulties in communication and 
understanding between participants from different milieux and social groups $[2,7,19,33]$. A serious level of improvement is also expected in the sphere of data protection, anonymity, and transparency on the technical side of the processes [21,91,92]. New and more visually attractive forms of plan presentation also increase responsiveness in the participation process and, to a certain extent, eliminate the absence of face-to-face communication between plan creators and other stakeholders [15,87]. This is crucial for target groups reluctant to enter virtual (nonpersonal) exchange without informal social interactions [7,19,82]. Since virtual exchange reduces the ability to ask questions [19], it leaves the virtual participants (if the meetings are mixed) on the margin of the conversation [93,94].

Other studies stated that some participants might withdraw from participation because they do not feel competent enough to share their opinion with professionals [95]. In contrast, some forms of virtual participation (e.g., voting, mobile applications) do not require a public display, thereby easing participation for those who feel embarrassed [96]. A simplification of planned design and its outcomes might be clearer to a wider range of participants through virtual reality (VR) and augmented reality (AR). As technology is an essential part of a smart city, it is natural that it plays a significant role in planning itself. The authors of $[97,98]$ emphasized that VR and AR greatly assist in good quality planning because they enable authentic simulation and visualization of planned interventions in space, thus allowing participants to make the right decision when deciding to either accept or decline the offered design. VR and AR are, nevertheless, new tools in planning; therefore, they require further improvements to present the scenario more realistically and engage a wider range of stakeholders by improving easy access, simple understanding, level of amusement, etc. $[99,100]$.

Some authors (e.g., [3,101-103]) argued that public participation suffers from formality, which does not fulfil its purpose of the true inclusion of stakeholders and citizens in the process. As noted by this study and confirmed by [12], this might significantly hinder participants' trust in the process and their motivation to get involved. New and virtual forms of presenting public discussion results (e.g., graphs, polls) increase transparency and, hence, trust [7]. In addition to the use of presentation forms, the technology enables video and audio recording [82], which greatly increases the dissemination, transparency, understanding of the discussed document, and the quality of the stakeholders' response in the ensuing participation rounds.

In conclusion, the COVID-19 pandemic has served as a change initiator in public participation, including participation in urban and regional planning. The changes were mainly directed toward the introduction of technology, with improvised and planned new forms of online participation. According to the results of this and other studies that dealt with the consequences of COVID-19 (e.g., [23,30,104]), new approaches and a shift toward virtual participation have already been considered the "new normal". In this sense, it is underlined that face-to-face communication and traditional forms of participation cannot be simply replaced by virtual forms of participation [2], but virtual participation offers new opportunities that were not possible in the traditional approach. Therefore, other studies (e.g., $[9,12,13,17,81]$ ) advocate a combined approach as the best solution for future participative processes, which is emphasized by the authors of this study, particularly for the field of urban and regional planning.

The shift toward a combined approach should flow in parallel with technological advances and their application in participation, along with the awareness-raising and education of all potential participants in the use of technology and the purpose of urban and regional planning in order to maximize the meaningfulness of the shift $[4,15,87]$. A combined approach in the post-COVID-19 era would spur a larger number of stakeholders and their diversity, which is considered the ultimate precondition for a successful and meaningful participatory process [2,3,7,12,82,95,105]. Before COVID-19, [2] explored technical and methodologically detailed solutions to improve virtual participation, which [81] conducted in the specific COVID-19 context. Their results can be used as a starting point when adjusting to a combined approach. Additionally, [7] noted that the practice of at 
least one face-to-face meeting should be kept, following the recommendations by [15] to hold the participation process in several rounds and by [87] to involve participation in the earliest stage of planning and keep it through the entire process.

Author Contributions: Conceptualization, M.P. and J.C.; methodology, M.P. and J.C.; software, M.P., J.C., G.C., F.M., O.O., S.T.M. and J.v.d.B.; validation, M.P., J.C., G.C., F.M., O.O., S.T.M. and J.v.d.B.; formal analysis, M.P.; investigation, M.P., J.C., G.C., F.M., O.O., S.T.M. and J.v.d.B.; resources, M.P., J.C., G.C., F.M., O.O., S.T.M. and J.v.d.B.; data curation, M.P.; writing-original draft preparation, M.P.; writing - review and editing, M.P., J.C., G.C., F.M., O.O., S.T.M. and J.v.d.B.; visualization, M.P.; supervision, M.P.; project administration, M.P. and J.C.; funding acquisition, M.P., J.C., G.C., F.M., O.O., S.T.M. and J.v.d.B. All authors read and agreed to the published version of the manuscript.

Funding: This research received no external funding.

Institutional Review Board Statement: Not applicable.

Informed Consent Statement: Not applicable.

Data Availability Statement: Data are available in a publicly accessible repository that does not issue DOIs. Publicly available datasets were analyzed in this study. These data sources can be found in the references.

Conflicts of Interest: The authors declare no conflict of interest. The funders had no role in the design of the study; in the collection, analyses, or interpretation of data; in the writing of the manuscript, or in the decision to publish the results.

\section{References}

1. Healey, P. The Communicative Turn in Planning Theory and its Implications for Spatial Strategy Formation. Environ. Plan. B Plan. Des. 1996, 23, 217-234. [CrossRef]

2. Hampton, S.E.; Halpern, B.S.; Winter, M.; Balch, J.K.; Parker, J.N.; Baron, J.S.; Palmer, M.; Schildhauer, M.P.; Bishop, P.; Meagher, T.R.; et al. Best practices for virtual participation in meetings: Experiences from synthesis centers. Bull. Ecol. Soc. Am. 2017, 98, 57-63. [CrossRef]

3. Maričić, T.; Cvetinović, M.; Bolay, J.C. Participatory Planning in the Urban Development of Post-Socialist Serbia. A Support to Urban Development Process, 1st ed.; École Polytechnique Fédérale de Lausanne (EPFL) Cooperation and Development Center (CODEV): Lausanne, Switzerland; Institute of Architecture and Urban \& Spatial Planning of Serbia (IAUS): Belgrade, Serbia, 2018.

4. Cairns, G.; Wright, G. A reflection on the mass production of scenarios in response to COVID-19. Futures Foresights Sci. 2020, 2, 1-5. [CrossRef]

5. Gohari, S.; Baer, D.; Nielsen, B.F.; Glicher, E.; Situmorang, W.Z. Prevailing approaches and practices of citizen participation in smart city projects: Lessons from Trondheim, Norway. Infrastructures 2020, 5, 36. [CrossRef]

6. Hall, P. Cities of Tomorrow: An Intellectual History of Urban Planning and Design in the 20th Century, updated edition; Blackwell: London, UK, 2002.

7. Jaeweon, Y.; Sae-Woom, J.; Dongoh, H.; Seung-Won, K.; Ju-Chul, J. Post COVID-19 Visioning of Urban Comprehensive Plan through Citizen Participation: Focusing on the Citizen Participation of Busan Metropolitan City. J. Korea Plan. Assoc. 2021, 56, 156-168.

8. World Health Organization. Available online: www.who.int/emergencies/diseases/novel-coronavirus-2019 (accessed on 25 May 2020).

9. Rooij, R.; Aalbers, K.; Hausleitner, B.; Newton, C.; Rocco, R. Education for the resilient city-Teaching and learning urban design and planning in COVID-19 times. Urban Des. Plan. 2020, 173, 119-124. [CrossRef]

10. Azizi, M.; Azar, A.; Dehghan Nayeri, M. Participatory decision making in the post COVID-19 period. Mod. Res. Decis. Mak. 2020, 5, 165-192.

11. Valdez, E.S.; Gubrium, A. Shifting to Virtual CBPR Protocols in the Time of Corona Virus/COVID-19. Int. J. Qual. Methods 2020, 19, 1-9. [CrossRef]

12. Bricout, J.; Baker, M.A.P.; Moon, W.N.; Sharma, B. Exploring the Smart Future of Participation: Community, Inclusivity, and People with Disabilities. Int. J. E-Plan. Res. 2021, 10, 94-108. [CrossRef]

13. Graziano, T. Smart Technologies, Back-to-the-Village Rhetoric, and Tactical Urbanism: Post-COVID Planning Scenarios in Italy. Int. J. E-Plan. Res. (IJEPR) 2021, 10, 80-93. [CrossRef]

14. Liang, Z.C.; Ooi, S.B.S.; Wang, W. Pandemics and their impact on medical training: Lessons from Singapore. Acad. Med. 2020, 95, 1359-1361. [CrossRef]

15. Rajhans, V.; Rege, S.; Memon, U.; Shinde, A. Adopting a modified Delphi technique for revisiting the curriculum: A useful approach during the COVID-19 pandemic. Qual. Res. J. 2020, 20, 373-382. [CrossRef]

16. Norris, P. Virtual democracy. Harv. Int. J. Press Politics 1998, 3, 1-8. [CrossRef] 
17. Mehmood, A.; Imran, M. Digital social innovation and civic participation: Toward responsible and inclusive transport planning. Eur. Plan. Stud. 2021, 29, 1870-1885. [CrossRef]

18. Olson, G.M.; Zimmerman, A. (Eds.) Scientific Collaboration on the Internet, 1st ed.; MIT Press: Cambridge, MA, USA, 2008.

19. Shirmohammadi, S.; Hu, S.; Ooi, W.T.; Schiele, G.; Wacker, A. Mixing virtual and physical participation: The future of conference attendance? In Proceedings of the IEEE International Workshop on Haptic Audio Visual Environments and Games (HAVE 2012) Proceedings, Munich, Germany, 8-9 October 2012; pp. 150-155.

20. Stanyer, J. The British Public and Political Attitude Expression: The Emergence of a Self-expressive Political Culture? Contemp. Politics 2005, 11, 19-32. [CrossRef]

21. Vromen, A. Building virtual spaces: Young people, participation and the Internet. Aust. J. Political Sci. 2008, 43, 79-97. [CrossRef]

22. Dubov, A.; Shoptaw, S. The value and ethics of using technology to contain the COVID-19 epidemic (Letter to the Editor). Am. J. Bioeth. 2020, 20, W7-W11. [CrossRef]

23. Torous, J.; Myrick, K.J.; Rauseo-Ripcupero, N.; Firth, J. Digital mental health and COVID-19: Using technology today to accelerate the curve on access and quality tomorrow. JMIR Ment. Health 2020, 7, 38848. [CrossRef] [PubMed]

24. Norris, P. Digital Divide: Civic Engagement, Information Poverty and the Internet Worldwide; Cambridge University Press: Cambridge, MA, USA, 2001.

25. Goodchild, M.F. Citizens as sensors: The world of volunteered geography. GeoJournal 2007, 69, 211-221. [CrossRef]

26. Gabrys, J. Programming Environments: Environmentality and citizen sensing in the smart city. Environ. Planning. D Soc. Space 2014, 32, 30-48. [CrossRef]

27. Papacharissi, Z. The virtual sphere: The internet as a public sphere. New Media Soc. 2002, 4, 9-27. [CrossRef]

28. Buheji, M.; Buheji, A. Planning Competency in the New Normal-Employability Competency in Post- COVID-19 Pandemic. Int. J. Hum. Resour. Stud. 2020, 10, 237-251. [CrossRef]

29. Park, H.-J. Urban Planning in Post-COVID-19 Era: Humanist Perspective Revisited. J. Econ. Geogr. Soc. Korea 2020, $23,247-261$.

30. Castka, P.; Searcy, C.; Fisher, S. Technology-enhanced auditing in voluntary sustainability standards: The impact of COVID-19. Sustainability 2020, 12, 4740. [CrossRef]

31. Mazzoleni, S.; Turchetti, G.; Ambrosini, N. The COVID-19 outbreak: From 'black swan' to global challenges and opportunities [Editorial]. Pulmonology 2020, 26, 117-118. [CrossRef] [PubMed]

32. Ting, D.S.W.; Carin, L.; Dzau, V.; Wong, T.Y. Digital technology and COVID-19. Nat. Med. 2020, 26, 458-464. [CrossRef] [PubMed]

33. Hudson-Smith, A.; Evans, S.; Batty, M. Building the virtual city: Public participation through e-democracy. Know. Techn. Pol. 2005, 18, 62-85. [CrossRef]

34. Thoneick, R. Integrating Online and Onsite Participation in Urban Planning: Assessment of a Digital Participation System. Int. J. E-Plan. Res. 2021, 10, 1-20. [CrossRef]

35. Anttiroiko, A.-V. Digital Urban Planning Platforms: The Interplay of Digital and Local Embeddedness in Urban Planning. Int. J. E-Plan. Res. 2021, 10, 35-49. [CrossRef]

36. Sameh, H.M.M. Public Participation in Urban Development Process through Information and Communication Technologies. Master's Thesis, Department of Urban Planning, Faculty of Engineering, Ain Shams University, Cairo, Egypt, 2011. Available online: www.cpas-egypt.com/pdf/Hend_Magdy/M.Sc/002Public-Participation-in-Urban-Planning.pdf (accessed on 26 November 2021).

37. Rio Declaration on Environment and Development. 1992. Available online: www.jus.uio.no/lm/environmental.development.rio. declaration.1992/portrait.a4.pdf (accessed on 26 November 2021).

38. Leipzig Charter on Sustainable European Cities (Leipzig Charter 2007). Available online: https:/ / ec.europa.eu/regional_policy/ sources/activity/urban/leipzig_charter.pdf (accessed on 26 November 2021).

39. Treaty of Lisbon. Available online: https://eur-lex.europa.eu/legal-content/EN/TXT/?uri=CELEX\%3A12007L\%2FTXT (accessed on 26 November 2021).

40. The New Leipzig Charter-the Transformative Power of Cities for the Common Good. Available online: https://ec. europa.eu/regional_policy/sources/docgener/brochure/new_leipzig_charter/new_leipzig_charter_en.pdf (accessed on 26 November 2021).

41. Hodge, G.; Gordon, L.A.D. Planning Canadian Communities: An Introduction to the Principles, Practice, and Participants, 5th ed.; Thomson Nelson Publishers: Toronto, ON, Canada, 2008.

42. Bundesbaugesetz (German Federal Building Act) vom 23. Juni 1960 Erster Teil: Bauleitplanung §2 Aufstellung der Bauleitpläne (6). Available online: www.stadtgrenze.de/s/bbg/1960/bbaug1960.htm (accessed on 12 July 2021).

43. Bundesbaugesetz (German Building Law) vom 18.08.1976 BGBI. I S. 2256 §2a Beteiligung der Bürger an der Bauleitplanung. Available online: www.bgbl.de/xaver/bgbl/start.xav?start=//*\%5B@attr_id=\%27bgbl176s2256.pdf\%27\%5D\#_bgbl_\%2F\% 2F*\%5B\%40attr_id\%3D\%27bgbl176s2256.pdf\%27\%5D_1628501890392 (accessed on 13 July 2021).

44. Europarechtsanpassungsgesetz Bau-EAG Bau (European Construction Law Adaptation Act) vom 24. Juni 2004, Stadtumbau §§171a-d Soziale Stadt §171e. Available online: www.bgbl.de/xaver/bgbl/start.xav?start=/ / $\left[@ a t t r \_i d=\% 27 b g b l 104 s 1359 . p d f \%\right.$ 27]\#_bgbl_\%2F\%2F*\%5B\%40attr_id\%3D\%27bgbl104s1359.pdf\%27\%5D_1628502700349 (accessed on 12 July 2021).

45. Busch, L. Bürgerbeteiligung in der Städtebaulichen Planung-das Beispiel der Kreisangehörigen Städte Schleswig-Holsteins. Ph.D. Dissertation, HafenCity Universität, Hamburg, Germany, 2009. Available online: https://repos.hcu-hamburg.de/bitstream/hcu/ 413/1/Diss_Busch.pdf (accessed on 7 July 2021). 
46. Reglamento 2159/1978 de Planeamiento para el desarrollo y aplicación de la Ley sobre Régimen del Suelo y Ordenación Urbana (Planning Regulation for the development and application of the Law on Land Regime and Urban Planning). 1978. Available online: www.boe.es/eli/es/rd/1978/06/23/2159 (accessed on 12 July 2021).

47. Delgado Pérez, G. La participación ciudadana en el planeamiento urbanístico y el fenómeno de la teledirección: Análisis crítico sobre el proceso de formación de los planes urbanísticos en España y la incidencia de la opinión de los ciudadanos en su redacción, tramitación y gestión posterior. Scr. Nova. Rev. Electrónica De Geogr. Y Cienc. Soc. 2007, 14, 245.

48. Ley 6/1998 sobre régimen del suelo y valoraciones (Land Regime and Valorization Law 6/1998). Boletín Oficial del Estado No. 89, 14 April 1998. Available online: www.boe.es/eli/es/1/1998/04/13/6 (accessed on 5 July 2021).

49. Mozo Amo, J. El urbanismo y la participación ciudadana. Encuentros Multidiscip. 2015, 50, 1-8.

50. Ley de los Derechos de Participación y Control Ciudadanos. Ley 26300, Diario Oficial ‘El Peruano (Rights of Citizen Participation and Control Law-Law No. 26300). Available online: https://www2.congreso.gob.pe/sicr/cendocbib/con5_uibd.nsf/76AA4A3 7BC523EA8052586DB00226C55/\$FILE/LEY-26300.pdf (accessed on 15 July 2021).

51. JNE \& UNDP. Guia de Participación Ciudadana del Perú. Lima; Jurado Nacional de Elecciones: Lima, Peru, 2008; Available online: www2.congreso.gob.pe/sicr/cendocbib/con4_uibd.nsf/B3465D6F1868627205257CD7005DE4B8/\$FILE/1_pdfsam_Guia_ de_participacion_ciudadana.pdf (accessed on 3 August 2021).

52. Guide on Public Participation in the Public Service; Department: Public Service and Administration—Republic of South Africa (DPSA). 2008. Available online: www.dpsa.gov.za/dpsa2g/documents/cdw/2014/citizenengagement.pdf (accessed on 13 July 2021).

53. Vitello, C. Updated Guide to Canada's Impact Assessment Act. 2020. Available online: https:/ / environmentaljournal.ca (accessed on 15 July 2021).

54. Impact Assessment Act [Enacted by section 1 of chapter 28 of the Statutes of Canada 2019, in force 28 August 2019, see SI/2019-86]. Available online: www.laws-lois.justice.gc.ca/PDF.1-2.75.pdf (accessed on 15 July 2021).

55. Ley 7/1985 Reguladora de las Bases del Régimen Local (Law Regulating the Bases of Local Governments). 1985. Available online: www.boe.es/eli/es/1/1985/04/02/7/con (accessed on 12 July 2021).

56. Bräuer, M.; Biewendt, T. Elektronische Bürgerbeteiligung in deutschen Großstädten 2004. Website-Ranking Herausgegeben von der Initiative eParticipation. Available online: www.initiative-eparticipation.de (accessed on 7 July 2021).

57. Wiegandt, C.-C.; Lobeck, M.; Märker, O.; Wolf, K.; Häußler, J.; Christ, S. Webbasierte Medien in der Stadtentwicklung: Bürgerbeteiligung und Bürgerengagement in der Digitalen Gesellschaft; BBSR-Online-Publikation Nr. 28/2017. 2018. Available online: https:/ / www.bbsr.bund.de/BBSR/DE/veroeffentlichungen/bbsr-online/2017/bbsr-online-28-2017-dl.html?_blob= publicationFile\%3D1 (accessed on 10 October 2021).

58. Real Decreto Legislativo 7/2015 por el que se Aprueba el texto Refundido de la Ley de Suelo y Rehabilitación Urbana (Urban Rehabilitation Law 7/2015). Available online: www.boe.es/eli/es/rdlg/2015/10/30/7/con (accessed on 3 July 2021).

59. Ley 19/2013 de Transparencia, Acceso a la Información Pública y buen Gobierno (Transparency, Access to Public Information and Good Governance Law). Available online: www.boe.es/eli/es/1/2013/12/09/19/con (accessed on 15 July 2021).

60. Rubio, G.; González, C.; López, L.; Pau, I.; Anes, S. Experiencia de e-participación en Rivas Vaciamadrid. In Proceedings CollECTeR Iberoamérica 2008; Universidad Politécnica de Madrid: Madrid, Spain, 2008.

61. Law on Planning and Construction. 2009. Available online: www.pravno-informacioni-sistem.rs/SlGlasnikPortal/eli/rep/sgrs/ skupstina/zakon/2009/72/11/reg (accessed on 2 July 2021).

62. Bill 189 An Act to Amend Various Acts to Address the Coronavirus (COVID-19), Coronavirus (COVID-19) Support and Protection Act, 2020, Chapter 6 of the Statutes of Ontario. 2020. Available online: https://www.ola.org/en/legislative-business/bills/ parliament-42/session-1/bill-189 (accessed on 15 July 2021).

63. Special Rules Relating to Declared Emergency, Ontario Regulation 149/20 made under the Planning Act. Available online: www.omtario.ca/laws/regulation/r20149 (accessed on 15 July 2021).

64. Decreto Legislativo No.1412 que aprueba la Ley de Gobierno Digital (Public Participation and the Digital Government Law), 2018, pp. 4-8. Available online: https:/ / cdn.www.gob.pe/uploads/document/file/353216/decreto-legislativo-que-aprueba-laley-de-gobierno-digital-decreto-legislativo-n-1412-1691026-1.pdf (accessed on 15 July 2021).

65. Ley de Desarrollo Urbano Sostenible (Sustainable Urban Development Law of 2021), 2018, pp. 2008-2010. Available online: https:/ / busquedas.elperuano.pe/normaslegales/decreto-legislativo-que-aprueba-el-codigo-de-responsabilidad-decretolegislativo-n-1348-1471548-8/ (accessed on 3 July 2021).

66. Manual para la Elaboracion de Planes de Desarrollo Metropolitano-PDM 2020 (Manual of Metropolitan Development Plans in 2020), 2020, p. 370. Available online: https://cdn.www.gob.pe/uploads/document/file/1481389/Manual\%20para\%20la\%20 Elaboraci\%C3\%B3n\%20de\%20Planes\%20de\%20Desarrollo\%20Metropolitano\%20-\%20PDM.pdf (accessed on 3 August 2021).

67. Stadt + Grün. Available online: https://stadtundgruen.de/artikel/buergerbeteiligung-nicht-nur-in-zeiten-von-corona-15492 html (accessed on 3 July 2021).

68. Ponto, J. Understanding and Evaluating Survey Research. J. Adv. Pract. Oncol. 2015, 6, 168-171.

69. Singleton, R.A.; Straits, B.C. Approaches to Social Research, 5th ed.; Oxford University Press: New York, NY, USA, 2009.

70. Pantić, M. Sustainable Development Perspectives for Serbian Mountain Areas: Lessons from the European Context. Ph.D. Thesis, TU-Dresden, Dresden, Germany, 2014. Available online: https://nbn-resolving.org/urn:nbn:de:bsz:14-qucosa-144339 (accessed on 1 July 2021). 
71. Instituto Nacional de Estadística Encuesta sobre Equipamiento y Uso de Tecnologías de Información y Comunicación en los Hogares, Notas de Prensa. 2020. Available online: www.ine.es/prensa/tich_2020.pdf (accessed on 3 July 2021).

72. Canadian Radio-Television and Telecommunications Commission (CRTC). Available online: https://crtc.gc.ca/pubs/cmr2019en.pdf (accessed on 7 July 2020).

73. Statistical Office of the Republic of Serbia (SORS). Educational Attainment, Literacy and Computer Literacy-Data by Municipalities and Cities; SORS: Belgrade, Serbia, 2013.

74. Smarter Together. Available online: www.smarter-together.eu/projects/citizen-stakeholder-engagement-munich (accessed on 12 September 2020).

75. Stadt Hildesheim-Online-Bürgerbeteiligung in der Stadtplanung. Available online: www.hildesheim.de/rathaus/pressemeldungen/ 2021-03-09/ online-buergerbeteiligung-in-der-stadtplanung.html?type=2\# (accessed on 23 May 2021).

76. Urban Digital. Available online: https://urban-digital.de/digitalisierung-stadt-in-zeiten-covid-19-teil-2/ (accessed on 3 July 2021).

77. Bill 197 An Act to Amend Various Statutes in Response to COVID-19 and to Enact, Amend and Repeal Various Statutes, Chapter 18 of the Statutes of Ontario. Available online: https:/ /www.ola.org/en/legislative-business/bills/parliament-42/session-1/ bill-197 (accessed on 15 July 2021).

78. Putnam, R.D. Bowling alone: America's declining social capital. J. Democr. 1995, 6, 65-78. [CrossRef]

79. Hahn, J. Soviet Grassroots: Citizen Participation in Local Soviet Government; IB Tauris: London, UK, 1988.

80. Lee, J.J.; Kim, Y.S.; Kim, H.; Kim, D.Y. The Present Status and Government Officials Recognition on the Citizen Participation in Comprehensive Plan-Focused on Municipalities of Gyeonggi-do. J. Urban Des. Inst. Korea Urban Des. 2015, 16, 5-16.

81. Henry, S.M.; Bazilian, D.M.; Markuson, C. Just Transitions: Histories and Futures in a Post-COVID World. Energy Res. Soc. Sci. 2020, 68, 101668. Available online: www.sciencedirect.com/science/article/pii/S2214629620302437 (accessed on 17 September 2021). [CrossRef]

82. Osafo, E. Engaging Communities in Challenging Times: Lessons Learned from the Master Gardener Program during the COVID-19 Pandemic. Adv. Dev. Hum. Resour. 2021, 23, 75-87. [CrossRef]

83. Fox, H.E.; Kareiva, P.; Silliman, B.; Hitt, J.; Lytle, A.D.; Halpern, S.B.; Hawkes, V.C.; Lawler, J.; Neel, M.; Olden, D.J.; et al. Why do we fly? Ecologists' sins of emission. Front. Ecol. Environ. 2009, 7, 294-296. [CrossRef]

84. Jiminez-Zarco, A.; Gonzalez-Gonzalez, I.; Sagio-Rubio, F.; Torrent-Sellens, J. The co-learning process in healthcare professionals: Assessing user satisfaction in virtual communities of practice. Comput. Hum. Behav. 2014, 51, 1303-1313. [CrossRef]

85. Fraser, H.; Soanes, K.; Jones, S.A.; Jones, C.S.; Malishev, M. The value of virtual conferencing for ecology and conservation. Conserv. Biol. 2016, 31, 540-546. [CrossRef]

86. De Filippi, F.; Coscia, C.; Guido, R. From smart-cities to smart-communities: How can we evaluate the impacts of innovation and inclusive processes in urban context? Int. J. E-Plan. Res. 2019, 8, 24-44. [CrossRef]

87. Rikanović, M.; Zindović, M.; Đurić, N.; Lalić, M. Analiza Urbanističkog Planiranja i Projektovanja u Srbiji sa Stanovišta Rodne Ravnopravnosti (Urban Planning and Design Analysis from the Gender Equity Perspective in Serbia); Žensko Arhitektonsko Društvo \& UN Women: Belgrade, Serbia, 2020.

88. Goldberg, G. Rethinking the public/virtual sphere: The problem with participation. New Media Soc. 2011, 13, 739-754. [CrossRef]

89. Jon, I. Reframing postmodern planning with feminist social theory: Toward "anti-essentialist norms". Plan. Theory 2020, 19, 147-171. [CrossRef]

90. Kupper, H.; Banks, L.; Bright, T.; Davey, C.; Shakespeare, T. Disability-inclusive COVID-19 response: What it is, why it is important and what we can learn from the United Kingdom's response. Wellcome Open Res. 2020, 5, 79. [CrossRef] [PubMed]

91. De Wijis, L.; Witte, P.; Geertman, S. How smart is smart? Theoretical and empirical considerations on implementing smart city objectives-a case study of Dutch railway station areas. Innovation. Eur. J. Soil Sci. 2016, 29, 424-441. [CrossRef]

92. Yigitcanlar, T.; Desouza, K.C.; Butler, L.; Roozkhosh, F. Contributions and risks of Artificial Intelligence (AI) in building smarter cities: Insights from a systematic review of the literature. Energies 2020, 13, 1473. [CrossRef]

93. Tang, A.; Neustaedter, C.; Greenberg, S. VideoArms: Embodiments for Mixed Presence Groupware. In People and Computers XX-Engage; Bryan-Kinns, N., Blanford, A., Curzon, P., Nigay, L., Eds.; Springer: London, UK, 2007; pp. 85-102. Available online: https:/ /link.springer.com/chapter/10.1007\%2F978-1-84628-664-3_8 (accessed on 12 September 2021).

94. Harry, D.; Green, J.; Donath, J. Backchan.nl: Integrating Backchannels in Physical Space. In Proceedings of the SIGCHI Conference on Human Factors in Computing Systems, Florence, Italy, 5-10 April 2008; Association for Computing Machinery: New York, NY, USA, 2009; pp. 1361-1370.

95. Green, R.A. The Delphi technique in educational research. SAGE Open 2014, 4, 1-8. [CrossRef]

96. McKenna, K.Y.A.; Bargh, J.A. Coming out in the age of the Internet: Identity "demarginalization" through virtual group participation. J. Personal. Soc. Psychol. 1998, 75, 681-694. [CrossRef]

97. Jamei, E.; Mortimer, M.; Seyedmahmoudian, M.; Horan, B.; Stojcevski, A. Investigating the Role of Virtual Reality in Planning for Sustainable Smart Cities. Sustainability 2017, 9, 2006. [CrossRef]

98. Olszewski, R.; Gnat, M.; Trojanowska, H.; Turek, A.; Wieladek, A. Towards social fuzzy geoparticipation stimulated by gamification and augmented reality. In Proceedings of the 13th International Conference on Natural Computation, Fuzzy Systems and Knowledge Discovery (ICNC-FSKD), Guilin, China, 29-31 July 2017; pp. 1363-1370. 
99. Imottesjo, H.; Kain, J.-H. The Urban CoBuilder-A mobile augmented reality tool for crowd-sourced simulation of emergent urban development patterns: Requirements, prototyping and assessment. Comput. Environ. Urban Syst. 2018, 71, 120-130. [CrossRef]

100. Fegert, J.; Pfeiffer, J.; Peukert, C.; Weinhardt, C. Enriching E-Participation through Augmented Reality: First Results of a Qualitative Study. In Changing Landscapes-WI 2020_Entwicklungen, Chancen und Herausforderungen der Digitalisierung, Proceedings of the 15th International Conference on Wirtschaftsinformatik, Potsdam, Germany, 8-11 March 2020; Gronau, N., Heine, M., Krasnova, H., Pousttchi, K., Eds.; GITO Verlag: Berlin, Germany, 2020; pp. 560-566.

101. Fraser, N. Transnationalizing the public sphere: On the legitimacy and efficacy of public opinion in a post-westphalian world. Theory Cult. Soc. 2007, 24, 7-30. [CrossRef]

102. Park, J.J.; Sung, H.J.; Park, C.H. Development and Application of Collective Spatial Decision Support System for Participatory Urban Planning. Seoul Stud. 2015, 16, 1-16.

103. Jeon, C.M.; Lee, H.C. The Trends and Characteristics of Engaged Urban Planning in Korea: Focused on 2030 Master Plans for Cheongju, Suwon, and Seoul. Seoul Stud. 2016, 17, 1-16.

104. Cilliers, J.; Simarmata, H.A.; Taufiqurrahman, T.; Olufemi, O.; Cimadomo, G.; Pantić, M.; Cap, C.; Treske, E.; Kumar, R.; Nakil, S.; et al. Virtual public participation during the COVID-19 crises. Hype or new normal for city planning? In Proceedings of the 56th ISOCARP World Planning Congress "Post-Oil City: Planning for Urban Green Deals", Doha, Qatar, 8-12 November 2020; pp. 1513-1525.

105. Nambisan, S.; Baron, R.A. Virtual customer environments: Testing a model of voluntary participation in value co-creation activities. J. Prod. Innov. Manag. 2009, 26, 388-406. [CrossRef] 